\title{
Effect of feeding sorbent and enzymes on heavy metal toxicity in young steers
}

\author{
S.R. Khamikoeva ${ }^{1}$, O.I. Bosieva ${ }^{1}$, V.Kh. Temiraev ${ }^{1}$, R.B. Temiraev ${ }^{1,3^{*}}$, \\ O.V. Pshikova ${ }^{2}$, L.A. Bobyleva ${ }^{3}$, E.Yu. Cis ${ }^{4}$
}

${ }^{1}$ Gorsky State Agrarian University, 362040, Vladikavkaz, 37 Kirov Street; ${ }^{2}$ Kabardino-Balkarian State University named after H.M. Berbekov, 360004, Kabardino-Balkarian Republic, Nalchik, Chernyshevsky St., 173 ; ${ }^{3}$ NorthOssetian State University named after K.L. Khetagurov, Vladikavkaz, 362025; ${ }^{4}$ Federal Science Center for Animal Husbandry named after Academy Member L.K. Ernst 142132,Moscow region, Podolsk City district, Dubrovitsy settlement, house 60, Russian Federation.

*Corresponding author e-mail: temiraev@ mail.ru

Journal of Livestock Science (ISSN online 2277-6214) 12: 341-345

Received on 3/10/21; Accepted on 20/11/21; Published on 10/12/21

doi. 10.33259/JLivestSci.2021.341-345

\begin{abstract}
It seemed to us a topical issue of achieving the goal of research to study the effect of the adsorbent preparations toxfin and MEC celloviridin G20x on the state of ruminal metabolism in fattening gobies, whose diets had an excess content of lead, zinc and cadmium salts. The objects of research were the animals of the Swiss breed. The duration of their fattening was 12 months before they reached the age of 18 months. To intensify growth and activate the processes of digestive metabolism due to better elimination of salts of heavy metals, it is advisable to jointly introduce adsorbent preparations toxfin in the amount of $1 \mathrm{~kg} / \mathrm{t}$ of feed and the multienzyme complex celloviridin G20x in the amount of $70 \mathrm{~g} / \mathrm{t}$ in the composition of the diets of fattening young cattle compound feed. Due to the combined feeding of the multienzyme complex and the toxfin adsorbent under the conditions of detoxification of HM salts in young fattening cattle of the 4-experimental group, it was possible to achieve superiority over the analogs of the control group in terms of average daily body weight gain by $11.10 \%$. The consequence of this relative to the control analogs in them was the activation of growth in the rumen of the number of representatives of ciliates (producers of cellulases and amylases) by $54.26 \%$ and bacteria of the Flavobacterium vitarumen group (producers of proteinases) - by 29.36\%. Due to this, the animals of the 4-test group had a significant $(\mathrm{P}<0.05)$ superiority over the control analogs in the contents of the rumen in terms of proteinase activity by $4.00 \%$, cellulases - by $1.77 \%$ and amylases - by $1.77 \%$. The combined feeding of the tested feed additives provided an increase in the rumen fluid of the bulls of the 4th test group relative to the control analogs of the propionic acid level by $3.00 \%$ with a parallel drop in the concentration of oil acids - by $4.7 \%$.
\end{abstract}

Key words: fattening steers; heavy metals; enzyme preparation; sorbent; growth; digestive metabolism 


\section{Introduction}

In recent years, domestic consumers' requirements for the environmental safety of the produced beef have sharply increased, taking into account the natural and climatic conditions of each region. One of the most important factors directly affecting the sanitary and hygienic properties of the meat of fattened gobies is the level of soil and forage crops contamination with various toxicants in the region. In a number of constituent entities of Russia, with a well-developed infrastructure of metallurgical enterprises (including on the territory of the Republic of North Ossetia - Alania), one of the key environmental factors negatively affecting the quality characteristics of meat products is the excessive accumulation of heavy metal salts (HM) in feed components of the diets of fattened animals (Temiraev et al., 2012; Osikina et al., 2012; Dubrovin et al., 2012; Kokaevaet al., 2020).

According to a number of researchers (Dzodzieva et al., 2015; Tedtova et al., 2013; Temiraev et al., 2008), excessive intake of HM salts with feed contributes to a decrease in the body weight gain of young ruminants for fattening, deterioration of the environmental safety of the resulting meat products. All these negative environmental consequences are due to the manifestation of a depressing effect on the state of the digestive metabolism of heavy metal ions in fattening animals. This problem is aggravated by the ability of HMs to gradually accumulate in the organs and tissues of gobies, to poison their body, helping to inhibit metabolic processes, reducing meat productivity and the quality of beef produced.

Under these conditions, one of the most effective ways of detoxification of HM salts is the introduction of feed preparations into their diets, adsorbents that bind them firmly on their surface in the gastrointestinal tract (GIT) and remove them from the animal's body, thereby increasing the ecological purity of meat gobies. Moreover, in the practice of feeding young ruminants on fattening, feed preparations of adsorbents of a new generation are being introduced more and more often. They often exhibit synergistic effects on metabolic processes with a wide range of biologically active additives (BAA), including multienzyme complexes (MEC) (Chabaev et al., 2018; Temiraev et al., 2020; Hamikoeva et al., 2021).

In this regard, it seemed to us a topical issue of achieving the goal of research to study the effect of the adsorbent preparations toxfin and MEC celloviridin G20x on the state of rumen metabolism in fattening gobies, whose diets had an excess content of lead, zinc and cadmium salts.

\section{Material and methods}

To solve this goal on the principle of analogous pairs in the conditions of the feeding farm SPK «Vesna»

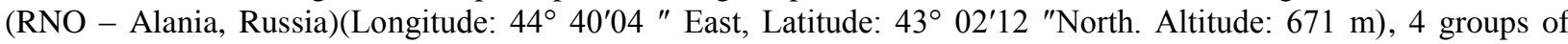
fattening bulls at the age of 6 months, 10 heads in each, were formed. The objects of research were the animals of the Swiss breed. The duration of their fattening was 12 months before they reached the age of 18 months. In the course of the research and production experience, the adsorbent preparations toxfin and MEC celloviridin G20x were consumed by young animals of the compared groups in the composition of mixed fodders by stepwise mixing with other ingredients in accordance with the nutritional standards of the Russian Agricultural Academy (2003) according to the scheme shown in Table 1. The content of $\mathrm{HM}$ ions ( $\mathrm{Zn}, \mathrm{Pb}$, and $\mathrm{Cd}$ ) in the rations (summer) for experimental animals (Table 2) was determined using an atomic adsorption spectrometer.

Celloviridin G20x - the drug is obtained by drying the filtrate obtained by submerged cultivation of the fungus Trichoderma reesei (viride) in a spray dryer. Fine, hygroscopic, amorphous powder from light yellow to dark brown, containing a complex of enzymes capable of hydrolyzing plant polysaccharides - cellulases, glucanases, xylanases, hemicellulases and others. Produced with cellulosolytic activity of 200 units/g, 1000 units/g and 2000 units/ g. The manufacturer of the drug is the Berdsk plant (Novosibirsk region, Russia). The rate of input into compound feed is 50-100 $\mathrm{g} / \mathrm{t}$ of compound feed.

Dry Toxfin is a feed additive designed to absorb aflatoxin from feed for farm animals and poultry. The company is the manufacturer of the drug Kemin Industries Inc.(USA). As the main components, Toxfin contains sepiolite and bentonite-montmorillonite. The sorption capacity of the drug is at least $95 \%$. Externally, it is a beige powder with a greenish tint. Practically insoluble in water. The input rate is $1-5 \mathrm{~kg} / \mathrm{ton}$.

In the selected feed samples, the content of HM salts was studied and their content was determined in the composition of the winter and summer rations for feeding the bulls of the compared groups. So, in the composition of the winter diet of the experimental animals, an excess of the maximum permissible concentrations (MPC) for zinc concentration was observed by 67.6-67.9\%, lead- by 63.0-64.2\%, and cadmium- by $59.4-60.5 \%$, in the composition of the summer diet this excess of the MPC values for the indicated elements was $65.1-66.2 \%, 61.0-62.4 \%$ and 63.1 $65.2 \%$.

Scar fluid samples were collected through the esophagus using a medical probe. The amount of volatile fatty acids (VFA) was determined by steam distillation in a Markgam apparatus. The content of heavy metal ions (HM) was determined by the atomic adsorption method on an AAZ-115-M1 spectrophotometer. Taking into account the difficulty of obtaining the contents of the rumen, the effect of the tested preparations on the state of ruminal metabolism in fattening young animals was studied according to generally accepted methods for only 3 animals from the 1-control group and the 4-experimental group with the best productivity.

The obtained digital material was subjected to mathematical processing with the calculation of the Student's criterion. 
Table 1 - Scheme of scientific and economic experience $(n=10)$

\begin{tabular}{|l|l|}
\hline Group & \multicolumn{1}{|c|}{ Feeding features } \\
\hline I-Control & Basic ration $(\mathrm{BR})$, in which an excess content of $\mathrm{Zn}, \mathrm{Pb}$ and $\mathrm{Cd}$ salts was wound \\
\hline II & BR + MEC celloviridin G20x in the amount of $70 \mathrm{~g} / \mathrm{t}$ of compound feed \\
\hline III & BR + adsorbent toxfin in the amount of $1 \mathrm{~kg} / \mathrm{t}$ of compound feed \\
\hline $\mathrm{I}$ & $\begin{array}{l}\text { BR }+ \text { MEC celloviridin G20x in the amount of } 70 \mathrm{~g} / \mathrm{t} \text { of compound feed } \\
+ \text { adsorbent toxfin in the amount of } 1 \mathrm{~kg} / \mathrm{t} \text { of compound feed }\end{array}$ \\
\hline
\end{tabular}

Table 2 - Daily ration for experimental bulls at the age of 6-9 months

\begin{tabular}{|l|c|c|}
\hline \multicolumn{1}{|c|}{ Index } & Required by the norm & Contained \\
\hline Green mass oats + vetch, kg & - & 22 \\
\hline Cereal-grain mixture, kg & - & 1.7 \\
\hline Era-3 concentrate, kg & - & 0.3 \\
\hline Table salt, g & 30 & 30 \\
\hline Complex of salts of microelements, g & - & 2.41 \\
\hline Disodium phosphate, g & - & 31 \\
\hline The diet contains: & & \\
\hline exchange energy, MJ & 43.0 & 49 \\
\hline dry matter, kg & 5.4 & 5.86 \\
\hline digestible protein, g & 565 & 566 \\
\hline crude fiber, g & 1135 & 1234.2 \\
\hline starch, g & 735 & 785.4 \\
\hline calcium, g & 41 & 47.5 \\
\hline phosphorus, g & 26 & 25.8 \\
\hline zinc, mg & 245 & 524.3 \\
\hline lead, mg & - & 124.26 \\
\hline cadmium, mg & - & 10.27 \\
\hline
\end{tabular}

\section{Results and Discussion}

The dynamics of the growth of the experimental bulls was observed following the results of the control individual weighing once a month. The weighing data at the beginning and at the end of the experiment for fattening young ruminants are shown in Table 3.

According to the results of the studies, it was found that by the end of fattening at the age of 18 months, the animals of the 4-experimental group had the highest body weight, which, according to this indicator, outstripped the bulls of the control group by $29.20 \mathrm{~kg}(\mathrm{P}<0.05)$ or $6.86 \%(\mathrm{P}<0.05)$. Based on these data, in terms of gross growth, young animals from the 4-test group also outstripped the control analogues by $28.30 \mathrm{~kg}(\mathrm{P}<0.05)$.

Due to the combined feeding of the multienzyme complex and the toxfin adsorbent under the conditions of detoxification of HM salts in young fattening cattle of the 4-experimental group, it was possible to achieve superiority over the analogs of the control group in terms of average daily body weight gain by $11.10 \%$. Moreover, the difference between the animals of the compared groups was statistically significant $(\mathrm{P}<0.05)$.

In the course of the experiment, the researchers found that when feeding the fattening gobies with the phytase enzyme with the adsorbent chelaton, an increase in live weight and an improvement in their slaughter indicators occurred (Osikina et al., 2012).

Taking into account the complexity of taking samples of ruminal fluid and conducting studies of their chemical composition, as mentioned above, we studied the effect of the tested dietary supplements on the indicators of the state of digestive metabolism in bulls from the 1-control and 4-experimentagroups. Table 4 shows data characterizing changes in the number of a number of microflora representatives, the $\mathrm{pH}$ value of the medium and the concentration of ammonia in the contents of the rumen of the animals of these groups, under the influence of the conditions of their feeding.

Under the conditions of using an adsorbent and an enzyme preparation for the removal of HM salts from the body, the $\mathrm{pH}$ value of the rumen fluid medium and the ammonia content in it in animals of the two compared groups were practically the same. This is justified by the fact that there were no significant $(\mathrm{P}>0.05)$ differences according to these parameters characterizing the intensity of digestive metabolism in young animals of the indicated groups.

At the same time, under the influence of the synergistic action between the tested preparations, the elimination of $\mathrm{HM}$ ions $(\mathrm{Zn}, \mathrm{Pb}$ and $\mathrm{Cd}$ ) from the body in the fattening bulls of the 4-test group was more effective. The consequence of this relative to the control analogs in them was the activation of growth in the contents of the rumen of the number of representatives of ciliates (producers of cellulases and amylases) by $54.26 \%(\mathrm{P}<0.05)$ and bacteria of the Flavobacterium vitarumen group (producers of proteinases) - by $29.36 \%(\mathrm{P}<0.05)$. 
Table 3 - Changes in live weight in experimental animals $(\mathrm{n}=10)$

\begin{tabular}{|l|l|c|c|c|}
\hline \multirow{2}{*}{ Index } & \multicolumn{4}{c|}{ Group of bulls } \\
\cline { 2 - 5 } & I-control & II & III & IV \\
\hline \multicolumn{5}{|c|}{ Live weight/ head, kg: } \\
\hline at the age of 6 months & $160.90 \pm 0.42$ & $160.80 \pm 0.26$ & $160.70 \pm 0.43$ & $160.80 \pm 0.58$ \\
\hline at the age of 18 months & $425.60 \pm 1.67$ & $446.30 \pm 2.22$ & $445.50 \pm 1.46$ & $454.80 \pm 2.13$ \\
\hline Live weight gain, kg & $264.70 \pm 1.52$ & $285.50 \pm 1.88$ & $284.80 \pm 1.37$ & $293.00 \pm 1.92$ \\
\hline
\end{tabular}

Table 4 - Changes in the number of a number of microflora representatives, the $\mathrm{pH}$ value of the medium and the concentration of ammonia in the contents of the rumen of animals $(n=3)$

\begin{tabular}{|l|c|c|}
\hline \multirow{2}{*}{\multicolumn{1}{|c|}{ Index }} & \multicolumn{2}{c|}{ Group of bulls } \\
\cline { 2 - 3 } & I-control & IV \\
\hline Number of ciliates, thousand/ ml & $457.0 \pm 4.22$ & $705.0 \pm 4.11$ \\
\hline Flavobacterium vitarumen, thousand/ ml & $125.0 \pm 0.34$ & $163.0 \pm 0.45$ \\
\hline Ammonia level, mg \% & $18.84 \pm 0.17$ & $18.92 \pm 0.30$ \\
\hline pH of the medium & $7.22 \pm 0.09$ & $7.24 \pm 0.13$ \\
\hline
\end{tabular}

Table 5 - Changes in the activity of enzymes in the rumen fluid of experimental animals $(n=3)$

\begin{tabular}{|l|c|c|}
\hline \multirow{2}{*}{ Name indicator } & \multicolumn{2}{|c|}{ Group of bulls } \\
\cline { 2 - 3 } & I-control & IV \\
\hline Activity analysis: amylase, mg starch & $23.78 \pm 0.42$ & $25.49 \pm 0.42$ \\
\hline cellulase, $\%$ & $16.30 \pm 0.31$ & $18.07 \pm 0.46$ \\
\hline proteinase, $\%$ & $42.68 \pm 0.30$ & $46.68 \pm 0.45$ \\
\hline
\end{tabular}

Table 6 - Changes in VFA concentration in the contents of the proventriculus experimental animals $(n=3)$

\begin{tabular}{|l|l|l|}
\hline \multirow{2}{*}{\multicolumn{1}{|c|}{ Index }} & \multicolumn{2}{c|}{ Group of bulls } \\
\cline { 2 - 3 } & I-control & IV \\
\hline amount of VFA, mmol/ $100 \mathrm{ml}$ & $8.11 \pm 0.35$ & $9.79 \pm 0.43$ \\
\hline Molar ratio of VFA,\%: & & \\
\hline acetic & $63.50 \pm 0.78$ & $63.30 \pm 0.71$ \\
\hline valerian & $1.60 \pm 0.49$ & $1.70 \pm 0.52$ \\
\hline nylon & $1.20 \pm 0.41$ & $1.00 \pm 0.33$ \\
\hline
\end{tabular}

Under the conditions of using an adsorbent and an enzyme preparation for the removal of HM salts from the body, the $\mathrm{pH}$ value of the rumen fluid medium and the ammonia content in it in animals of the two compared groups were practically the same. This is justified by the fact that there were no significant $(\mathrm{P}>0.05)$ differences according to these parameters characterizing the intensity of digestive metabolism in young animals of the indicated groups.

At the same time, under the influence of the synergistic action between the tested preparations, the elimination of $\mathrm{HM}$ ions $(\mathrm{Zn}, \mathrm{Pb}$ and $\mathrm{Cd})$ from the body in the fattening bulls of the 4-test group was more effective. The consequence of this relative to the control analogs in them was the activation of growth in the contents of the rumenof the number of representatives of ciliates (producers of cellulases and amylases) by $54.26 \%(\mathrm{P}<0.05)$ and bacteria of the Flavobacterium vitarumen group (producers of proteinases) - by $29.36 \%(\mathrm{P}<0.05)$.

These types of protozoa and microorganisms inhabiting the rumen of ruminants, as mentioned above, actively produce enzymes of the hydrolase class, which contribute to the intensification of the destruction of protein, fiber and starchy feed compounds in the contents of the rumen of fattened young cattle. This position is confirmed by the results of changes in the activity of the analyzed enzymes in the rumen fluid of the animals of the compared groups under the influence of the tested drugs, shown in Table 5.

As shown in Table 5, the combined use of HM in diets with an excess content of HM salts due to an increase in the number of these representatives of beneficial microflora made it possible to activate the processes of digestive metabolism in gobies. Due to this, the animals of the 4-test group had a significant $(\mathrm{P}<0.05)$ superiority over the control analogs in the contents of the rumen in terms of proteinase activity by $4.00 \%$, cellulases - by $1.77 \%$ and amylases - by $1.77 \%$. This contributed to a better level of digestion and assimilation of protein, fiber and nitrogen-free extractives (NFE) of rations by young animals of the 4-test group versus control analogues.

It has been experimentally proven that when the enzyme preparation pectofoetidin P10x in combination with bentonite was introduced into the feed of fattening gobies, the number of ciliates, the activity of proteinases and cellulases increased in the rumen of animals of the experimental group, which contributed to the optimization of the amount of volatile fatty acids (VFA) (Chabaev et al., 2018; Temiraevet al., 2020). The results of our studies are consistent with the indicated experimental data.

With an increase in the breakdown of poorly and readily soluble polysaccharides of feed under the action of enzymes secreted by the microflora of the gastrointestinal tract, their metabolites in the rumen of ruminants are actively fermented to form volatile fatty acids (VFA). By participating directly in the metabolic processes of VFA, 
they can influence the growth rate of young cattle for fattening while reducing the risk of intoxication with HM salts. The data of the influence of the tested feed additives on changes in the concentration of VFA in the contents of the rumen of the experimental animals are shown in Table 6.

It was found that due to the combined feeding of MEC preparations celloviridin G20x and toxfin, the processes of detoxification of HM salts were more efficient, therefore, fattening bulls of the 4-experimental group in the rumen fluid accumulated VFA more actively, reliably $(\mathrm{P}<0.05)$ outstripping the animals of the control group in this indicator by $1.68 \mathrm{mmol} / 100 \mathrm{ml}$ or $20.71 \%$. There were practically no significant differences in the concentration of acetic, valeric and caproic acids in the rumen liquid between the bulls of the compared groups.

Propionic acid is of more importance among the representatives of VFA for intensifying the growth of fattened young ruminants. Moreover, often its concentration in the rumen has an inverse biological relationship with the content of an undesirable representative of VFA - butyric acid.

As shown empirically, when optimizing the processes of digestive metabolism due to the rational use of cellulolytic enzymes in diets in young cattle, the amount of propionic acid in the rumen increases with a decrease in the mass fraction of propionic acid (Kokaevaet al., 2020).

As can be seen from the data obtained, shown in Fig. 3, the combined feeding of the tested feed additives provided an increase in the rumen fluid of the bulls of the 4th test group relative to the control analogs of the propionic acid level by $3.00 \%(\mathrm{P}<0.05)$ with a parallel drop in the concentration of oil. acids - by $4.7 \%(\mathrm{P}<0.05)$. The obtained research results are consistent with the changes in the average daily body weight gain of the fattening young animals of the compared groups with the effective use of an adsorbent and a multienzyme complex for removing HM salts from the body.

\section{Conclusion}

Consequently, to intensify growth and activate the processes of digestive metabolism due to better elimination of salts of heavy metals, it is advisable to jointly introduce adsorbent preparations toxfin in the amount of $1 \mathrm{~kg} / \mathrm{t}$ of feed and the multienzyme complex celloviridin G20x in the amount of $70 \mathrm{~g} / \mathrm{t}$ in the composition of the diets of fattening young cattle compound feed.

\section{References}

1) Chabaev M.G., Tedtova V.V., Baeva Z.T., Kononenko S.I., Tarchokov T.T., Chopikashvili L.V. 2018. Effect of different adsorbent doses on the morphological and biochemical composition of blood of bull calvesin detoxification of heavy metals. Journal of Pharmaceutical Sciences and Research. 5: 1122-1124.

2) Dubrovin A.I., Baeva Z.T., Dzodzieva E.S., Biboeva Z.Ya. 2012. Ecological and nutritional evaluation of different beef breed bulls fattenning on diets with excess heavy metals content. Animal Science. 4: 14.

3) Dzodzieva E.S., Kokaeva M.G., Temiraev R.B., Abramova G.A., Gurtsieva D.O. 2015. Comparative Assessment of the Quality of Meat of Gobies Fattened in the Technogenic Zone. Meat Industry. 2: 46-48.

4) Hamikoeva, S.R. Temiraev R.B., Chabaev M.G., Tsis E.Yu., Gappoeva V.S., Khabaeva Z.G., Gagloeva A.R. 2021. Effect of adsorbent and enzyme preparations on productivity of fattening steers with diets containing heavy metals. Journal of Livestock Science 12: 60-64. doi. 10.33259/JLivestSci.2021.60-64.

5) Kokaeva M.G., Temiraev R.B., Dzhaboeva A.S., Osikina R.V., Gazzaeva M.S., Shugusheva L.H., Sattsaeva I.K., Nerovnykh L.P., Arutyunova G.Y., Efendiev B.S. 2020. Method for increasing the ecological and food values of milk and dairy products. Journal of Livestock Science 11: 14-19.

6) Osikina R.V., Baeva Z.T., Dzodzieva E.S., Tsopanova Z. Ya. 2012. Assessment of the meat qualities of gobies of different breeds fed in the technogenic zone of North Ossetia - Alania. Bulletin of the Mountain State Agrarian University. -Vladikavkaz. - V. 49. - № 1-2: 95-98.

7) Tedtova V.V., Baeva Z.T., Dzodzieva E.S., Smelkov Z.A., Tsopanova Z. Ya. 2013. Morphological and biochemical parameters of the blood of Hereford gobies during the detoxification of heavy metals in feed. Bulletin of the Mountain State Agrarian University. - V. 50. - № 3: 127-130.

8) Temiraev R.B., Kairov V.R., Khamitsaeva E.S., Tuaeva T.K. 2008. Heavy metal contamination: how to keep pork safe. Compound feed.4:34-35.

9) Temiraev R.B., Sukhanova S.F., Tarchokov T.T., Osepchuk D.V., Baeva Z.T., Kubatieva Z.A., Kozhokov M.K., Kaloeeva Z.Yu., Khmelevskaya A.V. 2020. Effect of adsorbents in diets on production efficiency of broiler with high nutritional and ecological characteristics. Journal of Livestock Science 11: 26-32. doi. 10.33259/JLivestSci.2020.26-32.

10) Temiraev R.B., Kokaeva F.F., Tedtova V.V., Baeva A.A., Khadikova M.A., Abaev A.V. 2012. A method of increasing the dietary qualities of meat and improving metabolism in broiler chickens in the technogenic zone of the Republic of North Ossetia-Alania. News of the Mountain State Agrarian University. Vladikavkaz. -V. 49. -№. 4:130-133. 